\title{
Polysèmes
}

Revue d'études intertextuelles et intermédiales

15 | 2016

L'or et l'art

\section{Gold in the city? Symons's London: A Book of Aspects (1909)}

L'alchimie infernale d'Arthur Symons dans London: A Book of Aspects (1909)

\section{Bénédicte Coste}

\section{(2) OpenEdition}

Journals

\section{Electronic version}

URL: http://journals.openedition.org/polysemes/1144

DOI: 10.4000/polysemes. 1144

ISSN: 2496-4212

Publisher

SAIT

\section{Electronic reference}

Bénédicte Coste, « Gold in the city? Symons's London: A Book of Aspects (1909) », Polysèmes [Online],

15 | 2016, Online since 15 May 2016, connection on 30 April 2019. URL : http://

journals.openedition.org/polysemes/1144; DOI : 10.4000/polysemes.1144

This text was automatically generated on 30 April 2019.

Polysèmes 


\title{
Gold in the city? Symons's London: A Book of Aspects (1909)
}

L'alchimie infernale d'Arthur Symons dans London: A Book of Aspects (1909)

\author{
Bénédicte Coste
}

1 Part travelogue, part confession, Symons's London: A Book of Aspects (1909) presents itself as a panorama of London at the turn of the century. Like other writers, Symons explores the recent history of the capital and notes its vibrancy. Avowedly, the poet of London Nights and Silhouette ${ }^{1}$ does not aim at journalistic realism-which had informed literary descriptions of London along with social observations in the $19^{\text {th }}$ century ${ }^{2}-$ or mimesis, but constructs a multi-layered narrative where the arts of painting and dancing contribute to a larger reflection on urban writing and identity. His six chapters mix different genres-travelogue, memoir, architectural description, prose poem, autobiography-and turn London into the material for a meditation upon history, personal and collective memory.

2 Published in 1909, but written in 1906-1907, London exemplifies both the nineteenth century's sustained interest in developing a specialized language of urban life-"an attempt to articulate a condition of 'cityness' [...] in an era of unprecedented metropolitan expansion ${ }^{3}$-and an early Modernist aesthetics predicated on fragmentation and incompleteness. ${ }^{4}$ Likewise, Ford Madox Ford's The Soul of London (1905) is devoid of a single vantage point, presents a myriad of conflicting impressions, and abounds in details and micro-stories. ${ }^{5}$ Fragments of experience, consciousness and topography are woven into a string of narratives whose sole unity is that of the book. Such a technique transforms the perceived actual city into one representable in language.

3 Far more ambitiously, Symons's work confronts a similar task of capturing evanescence and multiplicity. As "a continual sequence of pictures", ${ }^{6}$ London demands a specific approach constituting Symons's poetic programme as early as 1892. Reviewing Henley's London Voluntaries, he noted: "what a sense of the poetry of cities, that rarer than pastoral poetry, the romance of what lies beneath our eyes, in the humanity of streets, if we had 
but the vision and point of view". ${ }^{7}$ In 1906, he invoked the literary tradition of Charles Lamb's London (14; 19-21; 35), chose a quotation from Balzac as an epigraph, ${ }^{8}$ and embraced the modernity of his beloved Baudelaire and Degas, to develop a carefully constructed poetic alchemy predicated on "a synaesthetic new art of city writing" ( Freeman 112). Such alchemy brings about a golden vision of the city all the more so as the city itself is auriferous: "those streets and pavements [...] turn by its alchemy into pure gold" (19). The confession-travelogue concludes however on a grimmer note as Symons explores Edgware Road which "seems to concentrate all the sordidness of London" (65). The reversed alchemy results in the discovery of a sense of "listlessness" (65) engulfing the inhabitants and comes as a marked contrast to his initial glorious vision of the city.

What follows explores the tension created by that last part to suggest that the darker parts of Symons's London function not so much as the result of a repression-namely of the ways of seeing London that had informed a majority of nineteenth-century descriptions-but herald a new economy of the gaze whose value remains to be assessed. Adopting Freeman's three literary discourses-empiricist, impressionist and symbolistof engagement with London between 1870 and 1914, ${ }^{9}$ Symons's vision of London also partakes of a larger concern with an economy of the gaze heralding later forms of spectatorship. The word is used in the sense of Guy Debord's definition in The Society of Spectacle:

The images detached from every aspect of life fuse in a common stream in which the unity of this life can no longer be reestablished. Reality considered partially unfolds, in its own general unity, as a pseudo-world apart, an object of mere contemplation. The specialization of images of the world is completed in the world of the autonomous image [...]. The spectacle presents itself simultaneously as all of society, as part of society, and as instrument of unification. As a part of society it is specifically the sector which concentrates all gazing and all consciousness. ${ }^{10}$

5 According to Debord, modern society-the society of the spectacle-can be defined as the society turning everything into a flux of images that tend to conglomerate into a single representation severed from the subject. Such a flux becomes a mirror image where one can only see one's deception and experience one's alienation. Carefully historicizing his analysis, Debord pointed out that the society of spectacle appeared at the turn of the twentieth century. Drawing on Debord's analysis, ${ }^{11}$ I argue that Symons's writings register and express such an advent, and should therefore be read not only as expressing a spectacular London but also as an expression of the society of the spectacle. London: A Book of Aspects is part of a larger array of texts informed by a spectacularized economy of the gaze. That economy relies on well explored ${ }^{12}$ rhetorical devices such as synaesthesia, itself integrated to the spectacularized gaze economy of early modernism. ${ }^{13}$

6 A distinguished critic of the arts, Symons was careful to document a new subjective and visual distribution. Arguing in 1892 that "the test of poetry which professes to be modern [was] its capacity for dealing with London, with what one sees or might see there, indoors or out", ${ }^{14}$ Symons departed from his more famous Victorian predecessors, firstly by his awareness of his position as spectator, and secondly, by the poetics he employed for conveying such a position. "I have always been apt to look on the world as a puppet-show, and all the men and women merely players, whose wires we do not see working" (28), Symons confessed, before contrasting his position with both that of his friend Frank Willard, a noted traveller-tramp, and that of the population seen on Edgware Road. For those categories, the "spectacle of human life" is certainly not one's "pleasure and satisfaction" (29). As opposed to the Debordian passive and alienated spectator, those 
take no delight in the spectacle of others, especially when those others turn them into symbols to be gazed at, commented upon and appreciated.

7 As W. Sharp recently noted, London appears as "a sign of excess, never securely captured, never evading closure". ${ }^{15}$ Nineteenth-century poets and prose-writers had confronted its multi-faceted flux by choosing static points of view and single topics. The city became an organic entity that could be stilled to be analysed more easily. By contrast, indulging in Baudelairean "baths of multitude", Symons often walks and adopts labile positions to explore London, going from Trafalgar Square, the "heart of London", to the parks and to Hampstead Heath from where "you are lifted over London, but you are in London" (10). Such a paradoxical location of "nearness and remoteness combined" is one instance of the "so unparalleled" sensations (10) that Symons continuously sought. Criss-crossing the city, Symons makes the ambiguous and unsettled experience of the city-walker, as described by Michel de Certeau ${ }^{16}$ His position remains as unfixed as his address to the reader, variously included in his ramblings or kept at a distance through the interplay of the "I" and the "you". However, the scenes on Edgware Road lack any identifiable focus: Symons negates his own presence and adopts an impersonal viewpoint, because his own visual economy has been derailed by the inhabitants.

In A Book of Aspects, the new economy of the gaze deploys itself along different lines predicated on an interart poetics. Several arts-photography, literature, painting, and music-hall dance-turn the text into the typically nineteenth-century genre of the animated panorama or the nascent cinematograph corresponding to the "real London [...] a continual sequence of pictures" (2), demanding a novel intermedial economy of perception and of description.

9 Indeed, Symons found a labile position from which natural elements became "always at work like a subtle painter, and London [...] a vast canvas prepared for the mist to work on" (2). London morphed into a writable surface for a painter-poet providing tools to engage in ekphrasis, a typical trope of Aestheticism, nurtured, in Symons's case, by his admiration for Whistler whose paintings marked the beginning of the modern acceptance and enjoyment of urban night time. Whistler's Wapping and infamous The Rocket: Nocturne in Blue and Gold set the tone for a different visual approach of the city while the eerie London nocturne became one of the most characteristic expressions of fin de siècle aesthetics. In A Book of Aspects glimpses or "aspects" the metropolis provided were experienced as brief visions that "stamped [themselves] in [one's] brain, an impression caught just at the perfect moment, by some rare felicities of chance" (53-54), Symons noted when recalling glimpsing from the outside at a stage as two doors were suddenly thrown open.

10 As Karl Beckson notes, A Book of Aspects was originally meant to be accompanied by the pictorialist photogravures of Alvin Langdon Coburn. Exemplifying "the concern of the more advanced pictorialism with 'modern' subjects, namely the twentieth-century city-a shift in attitude that triggered the final push towards photographic modernism", ${ }^{17}$ American-born photographer, Coburn had gone to London on a second visit in 1904 and started to work on the future Men of Mark (1913), making portraits of distinguished Edwardians such as G.K.Chesterton, H. Belloc, H.G. Wells, A. Bennett, and G.B. Shaw. Between 1906 and 1909 he also registered with the London County Council School of Photo-engraving to learn the technique of photo-engraving. After he and Symons met in 1906, they agreed to collaborate on a volume of prose and photographs of London and started visiting promising sites. In 1906-1907 their joint-book was successively offered to 
John Lane, Dent, Unwin, and Constable (Beckson 242). When it was repeatedly turned down, Coburn's friend and Minneapolis bookseller Edmund Brooks had the text privately printed in 1909 for himself 'and his friends"' (Beckson 242). Only two copies of that rare and genuinely intermedial book have survived. ${ }^{18}$

Coburn's photogravures display a large array of London sights, some of which wellknown, and try to offer a complete vision of the town's architectural, topographical and cultural diversity to match Symons's text. Industrial areas, boats and workers contrast with more bucolic settings ("The Canal at Maida Vale"). Those photogravures appear quite eerie, almost severed from the materiality of the city and contributing to severing the viewer from it. Photographing Leicester Square, Coburn displays a city tinged with both mystery and allure, with theatre lights glimmering through the rain. In his 1905 photograph of St Paul's Cathedral from Ludgate Circus, a wraithlike London seems to be hiding itself behind a huge billow of steam. Quite appropriately the picture was inserted at the end of the 1906 book, thus turning the materiality of the capital into evanescence or, quite literally, sublimating it.

Coburn's photogravures function as genuine "illustrations" to the printed word. The case is unusual enough to be noted as the late-nineteenth century was distinguished for the autonomy illustrations took vis-à-vis the (contents of the) printed page, for instance in The Yellow Book and The Savoy, two periodicals that Symons knew intimately, having been the latter's editor. Supposedly, both co-authors originally wanted the reader to experience the two languages of the printed word and of the image on the same page. ${ }^{19}$ Coburn photographed all the places that Symons mentioned including a stall in Edgware Road, which seems more peaceful than Symons's harsh description. A closer look suggests that those photogravures function as a beautification of the city and contribute to turning it into a spectacle that can be enjoyed by some, while others remain "unconcern [ed]" (65). Echoing Symons's spectacularization of London as well as his wanderings, those photogravures were later integrated in other publications, including Coburn's London (1909), ${ }^{20}$ thus regaining their independence as art views, ${ }^{21}$ and leaving no memory of their punctual echo to Symons's multi-layered poetics.

As M. Spie suggests, Symons had forged his masculine flâneur status and interart poetics during the Nineties when he was also a critic for The Star and regularly attended music hall shows. His extensive and intimate knowledge of the music halls provide "a unifying thread, a means of tying together the disparate, heterogeneous aspects of London" (Spie 82). The music hall and ballet dancing provide an analogy for ways of seeing the world when Symons evokes "the kaleidoscopic movement of the dance" (53). They also provide an analogy for his poetics:

A ballet is simply a picture in movement. It is a picture where the imitation of nature is given by nature itself; where the figures of the composition are real, and yet, by a very paradox of travesty, have a delightful deliberate air of unreality. (52)

In ballet dancing, the imitation of nature causes nature to become self-consciously surreal..$^{22}$ Such a paradox is also that of Symons's poetics itself aiming at giving readers the sense of London's perpetual movement, transforming it into a large-scale ballet, lifting it from its multifarious associations, carefully constructing a series of aestheticized views that have a "delightful deliberate air of unreality". The ballet morphs into "a spectacle which professes to be no more than merely beautiful [...] which provides, in short, the one escape into fairy-land which is permitted by that tyranny of the real which is the worst tyranny of modern life" (53). The reader is invited to see reality decomposed 
into parts that can be recomposed or reset to constitute an escapist fairyland later to be apprehended as a series of spectacles. Superimposed on reality, images replace it.

Unsurprisingly, the best position to experience a ballet turns out to be "from the wings [...]. It is almost to be in the performance oneself, and yet passive [...]. You see the reverse of the picture" (54). Such a position allows the onlooker not to be the dupe of the scene. ${ }^{23}$ Seen from that side-position, ballet appears in parts and gives "a contradictory appearance of mere nature and of absolute unreality" (55). More than a show, it becomes a spectacle constructed as such by self-conscious viewers. The metaphor conveys the progressive conglomeration of a perceived scene into a picture and the attendant transformation of the viewer into a spectator. The second move consists in transforming the picture into a potential work of art to be inserted as such within a world itself artificialized, spectacularized. "I tried to do in verse something of what Degas had done in painting" (59), Symons writes as a retrospective justification. His Degas-like text is a selfconscious universe replacing the common world, peopled by spectators ignoring others, including the (Debordian) bourgeois ${ }^{24}$ and the (Symonsian) poor.

Symons further praises "maquillage" to analyse the illusion make-up creates and to posit the equivalence of reality and its counterfeit, of gold and glitter: "I know that a delightful imposition is being practised upon me [...] and to me all that glitters shall be gold" (56). In a spectacularized world, the true nature of objects becomes irrelevant because all of them are images destined to take part in an ever-expanding spectacle. ${ }^{25}$ Maquillage and shows therefore also contribute to the "poetry of cities [...] wait[ing] for us in London (59). ${ }^{26}$ Such poetry arises from spectacularizing the city and locates the spectator in what Symons terms a "perverse" position-perverse because self-conscious-that $s /$ he enjoys as such.

That poetry is best apprehended by individuals on the move, which may account for Symons's personal memories of his nights in and out of Fountain Court, when going out meant "to get out of [him]self" (30); ${ }^{27}$ but more importantly of his lengthy description of "a strange friend of [his], an amateur tramp" (35) whom he sometimes accompanied in his wanderings. "Cigarette", or Frank Willard, Symons's friend whose ramblings are given an uncannily large part in the narrative, exemplifies such mobility. Incessantly crisscrossing the world, indulging in "curiosity [...] for its own sake" (37), he also experiences "a complete abandonment to his surroundings" (38). Permanently drifting along, Willard immerses himself within any place he happens to be therefore eschewing spectatorship. Symons concludes: "[...] few men have realized, as this man has realized, that 'not the fruit of experience, but experience itself, is the end"' (41). Embodying Pater's dictum in The Renaissance in unforeseen ways, Willard exemplifies one of the psychological and material effects of a huge city on individuals seen from an unexpected anthropological viewpoint. ${ }^{28}$ Like other friends of Symons discreetly present in his narrative, ${ }^{29}$ Willard already seems to be practising drifting (dérive) as done by the French Lettrists in the early 1950s when they wandered in old deprived areas of Paris. ${ }^{30}$ In that perspective A Book of Aspects also partakes of psycho-geography defined as the study of the effects of geographical disposition on the affective behaviour of individuals, ${ }^{31}$ a not unexpected rapprochement as psycho-geography was a counterstrategy to rampant spectacle. At one end of Symons's spectrum of the anthropological effects of modernity, one finds tramps and gypsies escaping pleasures Symons indulges in. ${ }^{32}$

Symons's Baudelairean poetical alchemy often produces gold, ${ }^{33}$ and he engages in aestheticist descriptions of light effects, both natural and artificial, underlining how 
London can be transformed into a golden or glittering city. ${ }^{34}$ His descriptions of lights have an uncanny building quality to which Coburn excellently responded. However, the alchemy may turn infernal, as Baudelaire's reader knows, and gold can revert to lead. Surprisingly, Symons whose vision of London appeared to be "symbolist", according to Freeman's typology, finally reverts to a negative vision of "Povertypolis".

In chapter V, the London fogs lead to an infernal experience: "as if one tried the experience of drowning or suffocating" (63). The reader is confronted with a series of morbid vignettes and comparisons: "putrescent", "rotting fruit"; a "dark tunnel" where lights go out. The cityscape morphs into a dreadful soundscape teeming with "roar and rumble", "sharp cries", "a stopping wheel", where a "helpless" individual walks "like a blind man" (63), before experiencing air-poisoning. Baudelaire's "infernal alchemy" informs Symons's concluding sentence:

[...] how strange, inexplicable, mysteriously impressive is this masque of shadows!

It is the one wholly complete transformation of the visible world, the one darkness

which is really visible, the one creation of at least the beauty of horror which has

been made by dirt, smoke and cities. (64)

Just as he had peeped at ballet dancing from the outside to probe its spectacular nature, Symons unmakes light effects by indulging in an astounding description of the Underground, and turns it into the noisy spectacle of darkness created by modern conditions of transportation. Such a vision making darkness visible is also part of the poetics of spectacularization, spectacularizing darkness in turn.

Echoed by Coburn's "The Canal at Chalk Farm", Symons's poetics culminates in the description of Chalk Farm Station, which appears as a rewriting of Dante's Inferno. ${ }^{35}$ The "eternal smoke" has "a rhetoric of its own" arising from "gaps", "vent-holes", and some "inner ferment" (64). Its explorers confront a "gaunt cavernous doorway leading underground" near a bridge over "an abyss of steam, which rises out of depths like the depths of a boiling pot" (64). Pursuing their descent, what meets their bewildered eyes is a

pot of noise and fire [...], pillars and pyramids of smoke [which] rise continually [...] hoarse cries, screams, a clashing and rattling, the sound of a movement which struggles and cannot escape, like the coiling of serpents twisting together in a pit. (64-65)

Tellingly never mentioned as such, the Underground becomes an invisible serpent with a pestilent breath, sending out clouds of "ghastly colour" over the abyss, projecting a "column of yellow blackness" (65) while "[m]ultitudes of red and yellow eyes speckle the vague and smoky darkness" (65). Dante, and Zola, whose L'Assommoir Symons translated in $1894,{ }^{36}$ contribute to this infernal picture, constructing a dark modern urban mythography.

21 Symons's panorama ends on the gloomy vision of Edgware Road inhabitants who provide him with "a comparative study in living" (64) as they paint a different picture. The place is an example of "squalor" where "innumerable people who have no less right than ourselves to exist naturally" are dehumanized (66). That dehumanization is conveyed through various scenes-the occasional "Punch and Judy" show, Salvation Army meetings, a blind beggar, or incidents creating "little crowds" (69) of onlookers. Since they have "no pleasures and no interests of their own to attend to", "any variety is welcome in the tedium of their lives" (72). Their depiction emphasizes their plainness, violence, ugliness, as well as their lack of "beauty", be it real or artificial, assuredly a major defect for any aesthete, or any spectator. 
22 As Symons's carefully constructed long sentence stresses the amount and disparity of wares of the Saturday market stalls, his meditation turns sour: "As I walk to and fro in Edgware Road, I cannot help sometimes wondering why these people exist, why they take the trouble to go on existing" (71). Faced with a lack of response to his investigations from the population, the explorer unmasks as a spectator confronted to an otherness he cannot circumscribe. Along with life and circumstances nature has unkindly dealt with Edgware Road inhabitants, who have lost "the capacity of accepting natural pleasures graciously, if such came to them" in London (72). Modern circumstances have turned them into creatures "[c]rawling between heaven and earth thus miserably [...] [who] have never known what makes existence a practicable art or a tolerable spectacle" (72-73, italics mine). As opposed to his praise of gypsies, ${ }^{37}$ Symons can only describe such otherness negatively. Modern urbanization has turned the explorer that Symons purports to be into a spectator trying to vindicate his condition, to make it hegemonic vis-à-vis the indifference of the population. By contrast, Coburn's "Edgware Road" shows a woman wearing a hat before her stall. Behind her are indistinct buildings with a sharp black and white contrast. His photogravure appears less violent than Symons's harsh judgment.

Symons had previously noted some of the effects of urbanization on his own behaviour. ${ }^{38}$ Modernity entails a loss of sensual contact with objects, natural elements, and fellow citydwellers. The modern city is noisy, and machines having superseded human activity are opposed to former and quieter times (17). In "In Praise of Gypsies" (1908), a blunter Symons declares: "Progress is a heavy wheel, turned backwards upon us". ${ }^{39}$ Such meditation on the anthropological effects of modern urbanization harks back to Ruskin's The Seven Lamps of Architecture (1849), among others, but in his updating Symons appears unable to link those changes explicitly to the vision meeting his eye on Edgware Road, refusing in fact to acknowledge that mediation and spectacularization go hand in hand.

His conclusion is predictable: "Life in great cities dehumanizes humanity" (75). Edgware Road inhabitants are blamed for their indifference to beauty. Also indifferent to their lives and future, ${ }^{40}$ they appear as incapable of reflection, ${ }^{41}$ marring London's panorama to the extent that Symons concludes by an evocation of the countryside and seaside villages where individuals keep a sense of beauty and have the "patience to go on living" (77). In a hospitable Cornish village people's voices are "cheerful" and there is "no tedium" (77). As a modern metropolis, London besmears poverty into ugliness, turning economic inequalities into aesthetic unbalance and destabilizing the economy of the gaze predicated on a position of spectatorship it had contributed to erect.

As was the case with many of Symons's short texts, A Book of Aspects was later included in Cities and Seacoasts and Islands, ${ }^{42}$ similarly exposing the results of spectacularization, ${ }^{43}$ and praising life in Cornwall, "a very long way from London" ${ }^{44}$ where some local owners refuse profit. ${ }^{45}$ Contrasting the friendly mores of the country and the urban sense of alienation and isolation, he concludes:

In this solitude, away from the people of cities, one learns to be no longer alone. In the city one loses all sense of reality and of relationship. We are hedged in from the direct agency of the elements; we are hardly conscious of the seasons but for their discomfort; we are in the midst of manufactured things, and might forget that bread grew in the ground and that water existed except in pipes and cisterns. And the moment we leave the city we come to remember again that men and women are not alone in the world, but have countless living creatures about them, not pets nor beasts of burden, and with as much right to the earth and sunlight. ${ }^{46}$ 
Symons's neglected Book of Aspects functions as "a romantical-psychological-pictorialsocial book" ${ }^{47}$ that he, as opposed to H. James, completed, but failed to publish as he had conceived it with Coburn. Modernity-urbanization and social transformation-has partly turned the city into a spectacle, dividing its population into three types: spectators, wanderers and inhabitants. At the extreme end of the spectacular spectrum are roamers, immersed in their surroundings, and at the other end, those still enjoying older forms of life, and who can rightfully be said to inhabit their place. In the middle ground, as a distinct, emerging category, are spectators à la Symons, self-consciously experiencing illusion and spectatorship. Whether confronted to London's beautiful sunsets or to more ignominious spectacles, spectators adopt unfixed positions where everything, including modern means of transportation, can be turned into a spectacle thanks to linguistic alchemy, i.e. a self-conscious use of language, itself having become autonomous, and producing in turn further dissociation from reality. Such a use of language fosters a sense of alienation acknowledged as one of the hallmarks of modernist description of the city. The poetics of modernism is also a spectacular poetics.

Such spectacularization contrasts with the sheer indifference of individuals lacking Symons's commodified desire, apathetic to the implicit sensation-searching aim of the spectacle, whether it comes from beautiful surroundings or from horrific scenes. Their indifference signals a blind spot in the spectacular politics of the turn of the century and most especially in the politics of Aestheticism and Decadence Symons contributed to elaborate. It also foregrounds another effect of modernity overlooked by Aesthetes and Decadents in their search for rare sensations ${ }^{48}$ Modernity severs spectators from sensual contact with objects and their fellow companions and turns them into consumers, into newly-born spectators of others. Symons's unfortunate comparisons to describe the plight of the underprivileged are symptomatic of the blind spot of the scopic economy of Aestheticism. Those who engage in alternative forms of being-Symons's analysis is too succinct here-do not appear on the picture that the spectacle paints. Or when they do, they become another spectacle on Edgware Road before fading into oblivion. Finally, they evade Symons's spectacularizing gaze, and remain mere figures on Coburn's aestheticizing photogravures, one of those who "never appeared". ${ }^{49}$

\section{BIBLIOGRAPHY}

Bailey, Peter. Music Hall: The Business of Pleasure. Milton Keynes: Open UP, 1986.

Baudelaire, Charles. Les Fleurs du Mal. Paris: Gallimard, NRF, $2^{\text {nd }}$ ed., 1996.

Beckson, Karl. Arthur Symons. A Life. Oxford: Clarendon Press, 1987.

Beckson, Karl (ed.). The Memoirs of Arthur Symons: Life and Art in the 1890s. University Park and London: Pennsylvania State UP, 1977.

De Certeau, Michel. The Practice of Everyday Life. Trans. Steven Randall. Berkeley; Los Angeles \& London: The U of California P, 1988. 
Coburn, Alvin Langdon. London. London and New York: Duckworth and Brentano's, 1909.

Coburn, Alvin Langdon.

http://www.photogravure.com/history/keyfigures_coburn.html (last accessed 4 April, 2016)

Crary, Jonathan. Techniques of the Observer: On Vision and Modernity in the Nineteenth Century. Cambridge: The MIT Press, 1990.

Crary, Jonathan. Suspensions of Perception: Attention, Spectacle and Modern Culture. Cambridge: The MIT Press, 1999.

Debord, Guy. The Society of Spectacle. Trans. Freddy Perlman. London: Black \& Red, 1977. http:// www.marxists.org/reference/archive/debord/society.htm (last accessed 4 April, 2016)

Debord, Guy. Euvres. Paris: Gallimard, 2004.

Freeman, Nicholas. Conceiving the City: London, Literature and Art 1870-1914. Oxford: OUP, 2007.

Madox Hueffer, Ford. The Soul of London: A Survey by Ford Madox Hueffer. London: Alston Rivers, 1905.

James, Henry. The Notebooks of Henry James. Chicago: The U of Chicago P, 1981.

Lyon, Janet. "Sociability in the Metropole: Modernism Bohemian Salons”. ELH 76.3 (Fall 2009): 687-711.

Parr, Martin, and Gerry Badger. The Photobook: A History, vol.I. London: Phaidon Press, 2004.

Sharp, William. "London and nineteenth-century poetry". The Cambridge Companion to the Literature of London. Ed. Lawrence Manley. Cambridge: CUP, 2011, 119-141.

Simmel, Georg. "The Sociology of Sociability”. Simmel on Culture. Eds. David Frisby and Mike Featherstone, London: Sage, 1997.

Spie, Michelle. "Romancing the City: Arthur Symons and the Spatial Politics of Aesthetics in 1890s London". Imagined Londons. Ed. Pamela K. Gilbert. New York: Suny Press, 2002, 69-84.

Symons, Arthur. "Mr Henley's Poetry". Fortnightly Review (August 1892), rpt. Studies in Two Literatures. London: Leonard Smithers, 1897, 186-203.

Symons, Arthur. London: A Book of Aspects. Minneapolis: Privately Printed for Edmund D. Brooks and His Friends, 1909.

Symons, Arthur. "In Praise of Gypsies”. Journal of the Gypsy Lore Society 1 (1908): 296.

Symons, Arthur. London: A Book of Aspects by Arthur Symons with Twenty Photogravures by Alvin Langdon Coburn. Minneapolis: Privately Printed for Edmund D. Brooks and His Friends, 1914.

Symons, Arthur. “Preface”. Silhouettes. London: Leonard Smithers, 1896.

Symons, Arthur. Cities and Seacoasts and Islands. New York: Brentano's, 1919.

Symons, Arthur. Selected Letters 1880-1935. Ed. Karl Beckson. London: Macmillan, 1989.

Weaver, Michael. Alvin Langdon Coburn, Symbolist Photographer 1882-1966: Beyond the Craft. New York: Aperture, 1986.

Zola, Émile. L'Assommoir. Trans. Arthur Symons. London: The Lutetian Society, 1894. 


\section{NOTES}

1. Symons was one of the first "to utilize London as a Symbolist image", Karl Beckson, Arthur Symons. A Life, Oxford: Clarendon Press, 1987, 88.

2. See for instance George Sims, How the Poor Live (1883), Joseph Conrad's Heart of Darkness (1897) and Jack London's The People of the Abyss (1903). Symons's indebtedness to Blake's "London" and De Quincey's “Confessions of an English Opium-Eater" is also obvious.

3. Nicholas Freeman, Conceiving the City: London, Literature and Art 1870-1914, Oxford: OUP, 2007, 3.

4. Also present in F. Madox Ford's narrative, The Soul of London: A Survey (1905), not to mention another text also illustrated by A. Langdon Coburn, London by G.K. Chesterton (1913) describing the Inner Circle Line route which a provincial woman is unable to exit. Coburn took pictures of Mansion House, the Tower, Blackfriars, the Temple and Westminster Bridge stations.

5. The Soul of London: A Survey by Ford Madox Hueffer, London: Alston Rivers, 1905.

6. A. Symons, London: A Book of Aspects, Minneapolis: Privately Printed for Edmund D. Brooks and His Friends 1909, 2. All references are to this edition.

7. A. Symons, "Mr Henley's Poetry", Fortnightly Review (August 1892), rpt. Studies in Two Literatures , London: Leonard Smithers, 1897, 186-203.

8. “[...] les idées sont dans l'air, elles vous sourient au coin d'une rue, elles s'élancent sous une roue de cabriolet avec un jet de boue." H. de Balzac, Scènes de la vie de province, tome 2, Les Célibataires.

9. According to Freeman, writers developed three discourses in line with contemporary artistic and, to a lesser extent, scientific innovations. "Empiricist" London derives from a positivist belief that the city can be mapped and understood by a process of investigation and analysis, giving rise to sociological enquiry and certain types of realist fiction; "impressionist" London is a city that can only be known fleetingly from a wholly subjective position; and "symbolist" London is mystical metropolis seen as either a portion of eternity too big for the eye of man, or as a series of secret patterns discernible only to the initiated, when they simply could not be deciphered by the neophyte. Symons partly embraced a symbolist discourse (Freeman 12-13).

10. Guy Debord, The Society of Spectacle, trans. Freddy Perlman, London: Black \& Red, 1977. http:// www.marxists.org/reference/archive/debord/society.htm (last accessed 7 February, 2016).

11. Other studies on visuality in the Victorian and early modernist times include Jonathan Crary, Techniques of the Observer: On Vision and Modernity in the Nineteenth Century, Cambridge: the MIT Press, 1990, and Suspensions of Perception: Attention, Spectacle and Modern Culture, Cambridge: The MIT Press, 1999.

12. For a gender analysis of Symons's London poems, see Michelle Spie, "Romancing the City: Arthur Symons and the Spatial Politics of Aesthetics in 1890s London", Imagined Londons, ed. Pamela K. Gilbert, New York: Suny Press, 2002, 69-84.

13. Another parallel can be made between Symons's anthropological analysis and Simmel's analysis of modern sociability: "This world of sociability, the only one in which a democracy of equals is possible without friction, is an artificial world made up of beings who have renounced both the objective and the purely personal features of the intensity and extensiveness of life in order to bring about among themselves a pure interaction, free of any disturbing material accent." G. Simmel, "The Sociology of Sociability”, Simmel on Culture, eds. David Frisby and Mike Featherstone, London: Sage, 1997, 124.

14. A. Symons, “Mr Henley's Poetry”, 188.

15. William Sharp, "London and nineteenth-century poetry", The Cambridge Companion to the Literature of London, ed. Lawrence Manley, Cambridge: CUP, 2011, 120. 
16. According to Michel de Certeau, the city gives rise to two experiences: the rational, ordered topographical city observed from a bird's-eye view, and the experience of the street, dangerous, ambiguous and unsettled. The first one is that of the city seen from above by geographers, and the second one is the city seen from below by walkers: "a second, poetic geography on top of the geography of the literal, forbidden or permitted meaning." The Practice of Everyday Life, trans. Steven Randall, Berkeley, Los Angeles \& London: The U of California P, 1988, 105.

17. M. Parr \& G. Badger, The Photobook: A History, vol.I, London: Phaidon Press, 2004, 74.

18. London: A Book of Aspects by Arthur Symons with Twenty Photogravures by Alvin Langdon Coburn, Minneapolis: Privately Printed for Edmund D. Brooks and His Friends, 1914. Museum of English Rural Life and Special Collections Service, University of Reading. I thank Professor Nicholas Freeman who alerted me to the existence of that edition.

19. The history of the text and the book composition, design and layout remains undocumented. 20. A.L. Coburn, London, London \& New York: Duckworth \& Brentano's, 1909. Most of the photogravures designed for A Book of Aspects appeared there. Some can be seen on http:// www.photogravure.com/history/keyfigures_coburn.html (last accessed on 7 February, 2016).

21. For instance Coburn published his picture of Saint Paul's in the Daily Graphic on 29 October 1909. On Langdon Coburn, see M. Weaver, Alvin Langdon Coburn, Symbolist Photographer 1882-1966: Beyond the Craft, New York: Aperture, 1986.

22. In his essay "The World as Ballet", Symons already wanted to "look at the dance, on the stage, a mere spectator" to see "a bouquet of living flowers, which have all the glitterings of artificial ones", The Memoirs of Arthur Symons: Life and Art in the 1890s, ed. Karl Beckson, University Park and London: Pennsylvania State UP, 1977, 245.

23. Such a position contrasts with Peter Bailey's analysis of the music hall "both [as] a public and private place where the multiple intimacies of its crowd [...] paradoxically afforded a kind of privacy”, Music Hall: The Business of Pleasure, Milton Keynes: Open UP, 1986, xvii.

24. In the 1970s Debord carefully distinguished spectators, bourgeois and bureaucrats whom he opposed to the proletariat and subsequently to autonomous subjects rejecting the society of spectacle.

25. In "Being a Word on Behalf of Patchouli", the preface to Silhouettes (1896), Symons had vindicated his preference for artificiality: "Only, personally, I prefer town to country; and in the town we have to find for ourselves, as best as we may, the décor which is the town's equivalent of the great natural décor of fields and hills. Here it is that artificiality comes in; and if anyone sees not beauty in the effects of artificial light, in all the variable, most human, yet most factitious town landscape, I can only pity him, and go my own way", Silhouettes, second edition revised and enlarged, London: Leonard Smithers, 1896, xv.

26. "I still think that there is a poetry in this world of illusion, not less genuine of its kind than that more easily apprehended poetry of a world, so little more real [...]. It is part of the poetry of cities, and it waits for us in London" (59). Earlier, Symons had credited Walt Whitman as the creator of "a vital poetry of cities" (48).

27. For an analysis of Fountain Court as both literary heart and "domestic retreat" (80) from the city, see Spie.

28. Interestingly, Symons had described his stay at the Willards' in Berlin in a Letter to Ernest Rhys: "We employed much of the time in social studies, and are prepared to write a scientific work in large 8vo on 'The Cafés of Berlin from 10.30 PM to $6 \mathrm{AM}$, sociologically considered. With Portraits and Autographs."' A. Symons, Selected Letters 1880-1935, ed. Karl Beckson, London: Macmillan, 1989, 83.

29. Unnamed are Ernest Dowson and Lionel Johnson whom Symons accompanied as an observer of their artificial experience of life. In "East and West End Silhouettes" Symons describes his chance encounters with friends and other intellectuals, and notes that the multitude of others and the indecipherable crowd have become a source of disillusionment dehumanizing human 
relations. In "Music Halls and Ballet Girls" (1890s), the places where an artist lives and eats "provide keys to his psyche as well as his artistic style", A. Symons, The Memoirs of Arthur Symons, 112.

30. "[...] la dérive se définit comme une technique du passage hâtif à travers des ambiances variées [...] ce qui l'oppose en tous points aux notions classiques de voyage et de promenade." “Théorie de la dérive" (1953), G. Debord, Euvres, Paris: Gallimard, 2004, 251.

31. "[...] l'étude des lois exactes et des effets précis du milieu géographique, consciemment aménagé ou non, agissant directement sur le comportement affectif des individus." G. Debord, "Introduction à une critique de la géographie urbaine" (1955), Euvres, 204.

32. As J. Lyon notes, Symons became interested in the Gypsies and published "In Praise of Gypsies" in the Journal of the Gypsy Lore Society, which was revived in 1907 along with the Gypsy Society with the aim of collecting and preserving the "genuine" Romani cultural lore, but also included histories of political persecutions. In his 1908 article Symons identified with the figure of the wandering gypsy: "[Gypsies] are the symbol of our aspirations, and we do not know it; they stand for the will for freedom, for friendship with nature, for the open air, for change and the sight of many lands; for all in us that protests against progress. Progress is a heavy wheel, turned backwards upon us." "In Praise of Gypsies", Journal of the Gypsy Lore Society 1 (1908), 296. J. Lyon demonstrates how the Gypsy culture was construed by Symons and others "as an eccentric bulwark against rationalist modernity", especially in the matrix of London. See Janet Lyon, "Sociability in the Metropole: Modernism Bohemian Salons", ELH 76.3 (Fall 2009) 701.

33. “Tu m'as donné ta boue et j'en ai fait de l'or”, Charles Baudelaire, "Ébauche d'un Épilogue pour

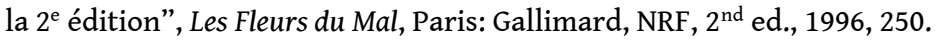

34. "[...] in London, it is the atmosphere that makes the picture, an atmosphere like Turner, revealing every form through the ecstasy of its colour" (5).

35. For an alternative reading see Freeman 188.

36. Émile Zola, L'Assommoir, trans. Arthur Symons, London: The Lutetian Society, 1894.

37. "[Gypsies] have the lawlessness, the abandonment, the natural physical grace in form and gesture, of animals; only a stealthy and wary something in their eyes makes them human", A. Symons, "In Praise of Gypsies", 296.

38. "We live by touching buttons and ringing bells" (15).

39. A. Symons, "In Praise of Gypsies", 296.

40. One man's exclamation heard by chance-“Twelve o'clock! We may be all dead by twelve o'clock!" (75)-summarizes the indifferent philosophy of the crowd Symons confronts.

41. Such a negative vision also appears albeit from a more ethnographical perspective in F. Madox Ford.

42. A. Symons, Cities and Seacoasts and Islands, New York: Brentano's 1919. Chapters include Spain, London, Britain, Ireland and Cornwall.

43. Cornish country places elicit "the sentiment, not of real things, but of a picture." A. Symons, “A Valley in Cornwall" (1904), Cities and Seacoasts and Islands, 245.

44. A. Symons, "At the Land's End" (1904), Cities and Seacoasts and Islands, 285.

45. "At the Land's End", 265.

46. "At the Land's End", 268.

47. H. James described his aborted project on "London Town" to Gosse in those terms. See The Notebooks of Henry James, Chicago: The U of Chicago P, 1981, 325.

48. Symons noted: "London was for a long time my supreme sensation, and to roam in the streets, especially after the lamps were lighted, my chief pleasure" (30).

49. Guy Debord: "[...] de ma vie, je ne suis apparu nulle part", Considérations sur l'assassinat de Gérard Lebovici (1988), CEuvres, 1550. 


\section{ABSTRACTS}

Part travelogue, part reflection on the intermingling of the arts, Symons's rarely discussed London: A Book of Aspects (1909) presents itself as a panorama of London at the turn of the century. However, the poet of London Nights and Silhouettes does not aim at journalistic realism but constructs a multi-layered narrative where the arts of painting and dancing contribute to a larger reflection on modern identity, all the more so as a rare, privately printed edition included photogravures by Alvin Langdon Coburn. Symons's poetic alchemy sometimes brings about a golden vision of the city but concludes on a grimmer note as it confronts the East End whose indifferent and plain inhabitants derail Symons's early modernist spectacularization of the city.

Marginalisé dans les études symonsiennes, London: A Book of Aspects (1909) se présente comme un récit de voyage doublé d'une réflexion sur la "mêlée des arts ». Le poète de London Nights et de Silhouettes ne vise nullement le réalisme journalistique mais élabore un récit feuilleté où l'art de la danse et de la peinture se mêlent à une réflexion plus large sur l'écriture, l'identité et la mémoire. Une version jamais publiée se doublait de photogravures d'Alvin Langdon Coburn inscrivant en outre la rencontre de l'image et du texte. Cette alchimie poétique produit, sinon de l'or, du moins une vision dorée de la ville mais se conclut sur une note plus sombre lorsque Symons explore l'East End. Contrariant l'économie scopique du texte, cette découverte révèle la spectacularisation du monde qui fut en partie l'invention du Mouvement Esthétique et du Symbolisme de la fin du XIX ${ }^{\mathrm{e}}$ siècle.

INDEX

Keywords: London, intermediality, spectacularization

oeuvrecitee London: A Book of Aspects

Mots-clés: Londres, intermédialité, spectacularisation

\section{AUTHORS}

\section{BÉNÉDICTE COSTE}

Bénédicte Coste is Professor of Victorian Studies at the University of Burgundy (EA 1486). Her research interests include the Aesthetic Movement in Britain including Walter Pater, Arthur Symons, and Ernest Dowson. She has translated essays by Pater, Symons, Vernon Lee, Bernard Berenson, John Addington Symonds and I.A. Richards. Her interest in Aestheticism has led her to the study of Victorian beliefs and she is currently engaged in a monograph on the topic. 